\title{
INDLEDENDE PERSPEKTIVER
}

\author{
Forandringsstaten og selvstændighedssamfundet
}

\author{
MAJA HOJER BRUUN, STINE KRØIJER OG MIKKEL RYTTER
}

Velfærdsstaten er blevet en selvfølgelig ramme om hverdagslivet i Danmark, og det er kun de færreste danske politikere og borgere, der anfægter dens grundlæggende berettigelse og eksistens. Siden socialreformen i 1933 og efterkrigstidens opbygning af velfærdsstaten har dens institutioner omfordelt økonomiske ressourcer og arbejdet frem mod at realisere visionen om, at alle borgere skal have adgang til uddannelse, sundhed, kulturelle tilbud og generel tryghed.

Siden 1990'erne er neoliberale ideer om markedsstyring, selvstyring og nødvendige nedskæringer imidlertid vundet frem. Sundhedssektoren har været præget af effektivisering og privatisering; i uddannelsessektoren har universitetet, gymnasieskolen og folkeskolen undergået markante reformer; $i$ arbejdet med integration er staten markant til stede $\mathrm{i}$ regulering, fordeling og overvågning af flygtninge og indvandrere, og den store kommunalreform fra 2007 har haft konsekvenser for afstanden mellem borgere og forvaltning, sektorsamarbejde, lokaldemokrati og borgerinddragelse. Danmark er for alvor blevet en del af den internationale markedsøkonomi, og samtidig med at job eksporteres til udlandet, sker en øget tilførsel af udenlandsk arbejdskraft til Danmark. I kølvandet på den globale økonomiske krise i 2007-2008 er det private forbrug dalet, den offentlige og den private gæld øget, og arbejdsløsheden er steget, hvilket blev anledning til blandt andet at indskrænke dagpengeperioden og hæve pensionsalderen. Offentligt italesættes håbet om, at væksten vil vende tilbage, så der kan blive råd til fremtidens velfærdssamfund.

I 2011 udgav politologen Ove Kaj Pedersen bogen Konkurrencestaten, hvor han argumenterede for, at velfærdsstaten har ændret sig til en konkurrencestat. Begrebet konkurrencestaten sammenfatter hele udviklingen fra 1980'ernes og 1990'ernes neoliberale økonomiske politik med introduktionen af nye styringsredskaber i den offentlige sektor, større deltagelse i den internationale konkurrence og reformpolitikken efter den økonomiske krise i 2007-2008. Den nye 
konkurrencestat har fire specifikke kendetegn: 1) Det er en ny type stat, der sigter mod at mobilisere og optimere borgere og erhvervsliv til international konkurrence i modsætning til velfærdsstaten, som søgte at værne samme mod ændringer i internationale økonomiske konjunkturer. 2) Konkurrencestaten promoverer et nyt syn på individet, hvor den enkelte er ansvarlig for sit eget liv. Dette dækker over et økonomisk rationale, hvor individets frihed er frihed til at realisere egne behov. Individet betragtes i konkurrencestaten som selvstændigt, rationelt og opportunistisk, og velfærdsstatens historiske vægtning af moralsk dannelse, demokrati og fællesskab træder i baggrunden. 3) Konkurrencestaten stræber efter og drives af dynamik og forandring, mens velfærdsstaten søgte stabilitet. Konkurrencestaten beror på en i princippet uendelig reformproces. 4) Konkurrencestaten er grundlæggende internationalt orienteret og søger at påvirke og tilpasse sig til internationale omgivelser, hvorimod velfærdsstaten i højere grad lukkede sig om sig selv og sine borgere (Pedersen 2011:12).

Pedersens bog og dens konklusioner blev genstand for stor offentlig debat, og kort efter dens udgivelse blev begrebet omfavnet af tidligere finansminister Bjarne Corydon fra Socialdemokraterne. I Politiken den 23. august 2013 konkluderede han, at konkurrencestaten er den moderne udgave af velfærdsstaten, og at den er kommet for at blive. Han udtalte i den anledning: „Sandheden er, at vi er i fuld gang med en voldsomt positiv dagsorden, der handler om at styrke og modernisere velfærdsstaten, og at resultatet af den forandring vil være et langt bedre samfund, end det vi har i dag.“ Corydon fortsatte: „Jeg tror på konkurrencestaten som den moderne velfærdsstat [...] hvis man skal sikre opbakning til velfærdsstaten, må man fokusere på kvaliteten af de offentlige serviceydelser frem for på overførselsindkomster" (ibid.). Ove Kaj Pedersens analyse gik således fra at være en model af konkrete organiseringsformer og forandringsprocesser til at blive en meget konkret model for samme. Konkurrencestaten er i de forløbne år blevet en samtidsdiagnostik og et bredt anvendt begreb, der såvel har dannet udgangspunkt for kritik af tingenes tilstand (se fx Illeris 2014 om uddannelsesområdet) som det har været et argument for „nødvendige reformer“.

Med denne indledning vil vi med udgangspunkt i antropologisk teori om velfærdsstater, tid og forandring samt den regionale etnografi fra Skandinavien udfordre begrebet „konkurrencestaten“ som den eneste mulige karakteristik af velfærdsstaten anno 2016. Den regionale etnografiske litteratur har i årtier fremhævet, hvordan velfærdsstaten formede og var formet af centrale værdier som lighed, egalitær individualisme, selvstændighed og fællesskab i de skandinaviske lande (Gullestad 1992a; Lien, Lidén \& Vike 2001; Bruun, Jakobsen \& Krøijer 2011). Hensigten med Tidsskriftet Antropologis to temanumre om velfærdsstaten er at udforske, hvad der sker med disse værdier og dermed med antropologiens 
regionale portvagtsbegreber, hvis vi vitterligt står midt i fremkomsten af en konkurrencestat. Hvor andre analyser af velfærdsstatens udvikling har betonet den internationale udbredelse af neoliberale reformer og Danmarks placering i den internationale økonomi, vil vi undersøge, hvordan den samfundsmæssige samtale om velfærdsstatens forandring og eventuelle afvikling hænger sammen med centrale kulturelle værdier og med forestillinger om, hvad forandring er og bør være. Når vi i denne indledning anvender begrebet ,velfærdsstat“, beror det således på en situering af den danske velfærdsstat i dens konkrete historiske, økonomiske, sociale og kulturelle kontekst. Således har Gøsta EspingAndersen (1990) identificeret den skandinaviske velfærdsmodel som en såkaldt universalistisk velfærdsmodel, kendetegnet ved en omfangsrig offentlig sektor, højt skattetryk og udvidede forsikringsordninger. ${ }^{1}$ I forhold til den regionale antropologiske litteratur om Skandinavien er det vores påstand, at reformerne af velfærdsstaten - nye styringsværktøjer og effektiviseringstiltag samt krav om selvudvikling og aktivitet - påvirker indretningen af, hvem der står uden for og inden for samfundets moralske og økonomiske fællesskab.

Vi introducerer to nye begreber - forandringsstaten og selvstændighedssamfundet, der sammenfatter vores analyse af velfærdsstaten og velfærdssamfundets moralske økonomi. De to begreber bringes i dialog med temanumrenes ni artikelbidrag, der fra forskellige positioner i og uden for statens institutioner tager temperaturen på forandringerne. Forandringsstaten er en stat med forandring som sit omdrejningspunkt, og frem for en konkurrencestat taler vi altså om en forandringsstat, hvor forandring er blevet et mål i sig selv. Forandringer er på én gang statens etos og selve genstanden for de statslige politikker. Begrebet selvstændighedssamfundet beskriver samfundets moralske økonomi, der ligger til grund for forandringsstaten. Ifølge Ove Kaj Pedersen er ét af kendetegnene ved konkurrencestaten en overgang fra moralisme til økonomisme og en bevægelse fra dannelse og fællesskab til opportunisme (Pedersen 2011:15). Men økonomismen indebærer også en bestemt fordring og moralitet om selvstændighed, som artiklerne i disse to temanumre tegner konturerne af. Hvor der almindeligvis er tale om en stigende individualisering og individualisme, kan vi på baggrund af de etnografiske bidrag og en ny fortolkning af det kulturelle tema egalitær individualisme og selvstændighed (Gullestad 1992a; Krøijer \& Sjørslev 2011) iagttage, hvordan borgere i dag i højere grad og på nye måder forventes at udvise selvstændighed og evnen til at „klare sig selv“".

Efter en gennemgang af, hvordan antropologien har beskæftiget sig med politisk kultur og værdier i Skandinavien, forandring samt centrale tilgange til antropologiske forståelser af staten, vil vi i denne indledning fremhæve tre spændingsfelter, som vi kalder henholdsvis spændingsfeltet mellem individ og 
fællesskab, krydsende tidsligheder og nye mekanismer for inklusion og eksklusion, med det mål at tegne konturerne af velfærdsstatens forandringsproces. De tre spændingsfelter går i dialog med Ove Kaj Pedersens fire kendetegn for konkurrencestaten (nævnt ovenfor) og peger på særlige friktioner og selvforstærkende processer af acceleration og eksklusion.

\section{Værdier og regionale portvagtsbegreber i forandring?}

På mange måder deler Ove Kaj Pedersen antropologiens interesse i at se på sammenhænge mellem strukturelle forandringer og værdier, politik og forestillinger om samfund, individ og fællesskab. I bogen Konkurrencestaten er det en central pointe, at idealer, normer og værdier udgør grundlaget for al politik, og det er i ændringer i den politiske kultur, vi skal finde grundlaget for forandringer i statens opgaver, organisation og ledelse (Pedersen 2011:34). Pedersen præsenterer en Foucault-inspireret model, med hvilken man kan studere institutionernes historie og forskydninger i diskurser og værdier og derigennem få indsigt $i$, hvordan samfundet forandres. Politisk kultur vedrører ifølge Pedersen „kun de idealer og værdier, der kommer til udtryk i beslutninger, som træffes af autoritative organisationer ( $\mathrm{fx}$ parlamenter og regeringer), og som efterhånden bliver til normer og holdninger, der dominerer 'vort' syn på 'os selv' og de udfordringer, 'vi' som fællesskab står over for" (op.cit.33).

Denne forståelse af politisk kultur hænger fint sammen med Pedersens version af den genealogiske metode, hvor idealer og værdier findes i politiske diskurser, som "siver" ned igennem samfundet fra den politiske elite og internationale organisationer såsom EU. Over for dette står et antropologisk kulturbegreb, som fremhæver, at individet er indfældet i fleksible fællesskaber (Hastrup 2004) og må forholde sig til mange krydsende loyaliteter (Vike 2015). Kultur er noget, alle gør, og kan ikke antages kun at hidrøre fra „toppen“ af samfundet og brede sig derfra. ${ }^{2}$ Selv om der fra toppen af samfundet måske tales om hastig forandring, kan folk andre steder i samfundet opleve kontinuitet i værdier eller ligefrem stilstand. Antropologer har fremhævet den ulige distribution af nye strukturer, viden og praksis. Eksempelvis skriver Shore og Wright (1997) om, hvordan policyændringer også kan starte nedefra, ved at lokale institutioner begynder at agere på nye måder, eller at nye former for politiske argumenter begynder at vinde frem på en spredt og ikke centralt orkestreret måde. Formel politik er i sådanne tilfælde i lige så høj grad respons på politiske ændringer, som de er udgangspunkt for dem.

Selv om forfatterne i nærværende to temanumre på mange måder deler Pedersens ambition om at adressere, hvordan institutionelle og værdimæssige forandringer 
hænger sammen, er det etnografiens og antropologiens styrke at belyse, hvordan ændringer opstår, optages og forhandles lokalt i folks arbejds- og hverdagsliv, uden at antage, at forandringer starter med formelle politiske beslutninger. De etnografiske beskrivelser i temanumrene søger at indfange erfaringer og sætte billeder på samfundsmæssige transformationer. Samtidig er det vores ærinde i denne indledning at undersøge forandring og den samfundsmæssige samtale om forandringer af velfærdsstaten, altså at gøre forandring og transformation til et empirisk objekt for antropologien om Skandinavien.

Når antropologer sætter politiske og institutionelle forandringer ind $i$ en bredere teoretisk og historisk kontekst, støtter vi os ofte til andre etnografiske beskrivelser og antropologisk teori, der er vokset ud af studier af de pågældende etnografiske regioner (Fardon 1990). I Skandinavien har den regionale etnografi i høj grad beskæftiget sig med forholdet mellem værdier og hverdagsliv. Dette gælder især begrebet lighed og Marianne Gullestads begreber „egalitær individualisme“ og „lighed som enshed“ (Gullestad 1992a), som på mange måder har fået karakter af ,gatekeeping concepts“ eller portvagtsbegreber (Appadurai 1986). Ifølge Appadurai er portvagtsbegreber forsimplede teoretiske begreber, der står som metonymer for hele samfund eller regioner og fører til stillestående analyser, fordi antropologer blindt reproducerer portvagtsbegreberne. Fardon (1990) fremhæver derimod, at den regionale etnografi og portvagtsbegreber sigter mod at kvalificere den antropologiske forskning i bestemte regioner. Når vi nærlæser nogle af de klassiske studier af Skandinavien, făr vi således et mere nuanceret billede af regionen. Ifølge Marianne Gullestad (1992a) er Skandinavien godt nok karakteriseret ved lighed og egalitær individualisme, men det indebærer en række spændingsforhold, fx mellem fællesskab og lighed på den ene side og individualisme og selvstændighed på den anden. Hun betoner, at skandinaver oplever ulighed og forskellighed som problematisk, hvorfor sidstnævnte i mange, men ikke alle sammenhænge underkommunikeres eller udgrænses (Gullestad 1992b). ${ }^{3}$ Inden for det seneste årti har flere antologier/temanumre føjet væsentlige pointer til den regionale forskningstradition: Lien, Liden og Vike (2001) understreger, at lighedsideologien ikke skal forveksles med reelt eksisterende lighed, mens Bruun, Jakobsen og Krøijer (2011) viser, at lighed og andre kulturelt værdsatte samværsformer også genererer uligheder, udstødelse og hierarkier.

\section{Velfærdsstaten som forandringsprojekt}

Ove Kaj Pedersen beskriver en ændring af det danske samfund fra velfærdsstat (1950-1990) til konkurrencestat (1990-). Inspireret af Michel Foucaults metode 
skitserer han disse to historiske epoker siden Anden Verdenskrig. Epokerne er kendetegnet ved hvert sit bestemte videnssystem (episteme), som sætter grænser for, hvad der kan tænkes og menes. Konkurrencestaten indebærer fx ifølge Pedersen en forskydning i opfattelsen af borgeren fra aktiv medborger til enten kompetent deltager i den internationale konkurrence eller forbruger af offentlige ydelser. På den ene side fremstår forskellene mellem velfærdsstaten og konkurrencestaten som altomfattende og epokale, men på den anden side omtales velfærdsstaten og konkurrencestaten som to typer velfærdsstater, hvor konkurrencestaten blot er en $n y$ form for velfærdsstat. Vi vil her ikke forsøge at „udmåle“ graden af reel forandring eller tage stilling til, om der er tale om en ny (velfærds)statsform eller ej. I stedet vil vi træde et skridt tilbage og rejse en grundlæggende diskussion om, hvordan folk erfarer forandring, og hvordan forandring kan forstås teoretisk, når velfærdsstaten skildres som et konstant forandringsprojekt. Vores grundlæggende tese er, at samtidig med at der foregår en forandring af velfærdsstaten, foregår der også en forandring af vores samfundsmæssige samtale $\mathrm{om}$ forandring. Ideer om forandring er ganske enkelt ikke, hvad de har været.

Ove Kaj Pedersen benytter sig af begreberne „tilpasning“ og „påvirkning“ til at beskrive den forandring, som velfærdsstaten har undergået siden 1990'ernes begyndelse (Pedersen 2011:14). Begreberne indebærer, at ændringer i de internationale omgivelser har en direkte konsekvens for udviklingen i Danmark, som dog også antages i nogen grad at kunne påvirke de eksterne betingelser gennem politiske beslutninger. Overstatslige politiske og økonomiske processer betyder ifølge Pedersen, at staten i højere grad må være internationalt organiseret og påvirke de internationale beslutningsprocesser, samtidig med at den dynamisk må forsøge at tilpasse sig forandringer i den internationale økonomi. ${ }^{4}$ Spørgsmålet er dog, om „tilpasning“ og „påvirkning“ er de mest egnede begreber til at forstå forandring. For er det virkelig sådan, at alle forandringer kommer „oppefra“, og det danske samfund enten påvirkes eller tilpasser sig? ${ }^{5}$

Flere af bidragene i disse to numre af Tidsskriftet Antropologi fremhæver, at man ikke skal begrænse sin teoretiske forståelse af forandring til en altomfattende modernitet. Allerede før debatten om „multiple modernities“ (Eisenstadt 2000; Englund 1996) pegede Gullestad på en særlig skandinavisk version af modernitet, som er kendetegnet ved egalitær individualisme (Gullestad 1989, 1992a). Med modernitet er der altså ikke tale om en slags uafvendelig kulturel og social homogenisering, men at forskellige grupper giver de samme begreber og værdier forskellig betydning (Gullestad 1992b:181). Flere artikler i de to numre af Tidsskriftet Antropologi beskriver, hvordan de mennesker, som er en del af velfærdsstatens mangeartede institutioner, håndterer forandringerne og policyinitiativer „oppefra“ og „udefra“ ved at trække linjer tilbage i tiden, gen- 
opfinde traditioner og værdier (jf. Hobsbawm \& Ranger 1983) og skabe nye kontinuiteter (oxymoronet er intenderet). Skolelærere fortolker og forhandler politiske tiltag og nye krav lokalt i klasseværelserne i lyset af deres tidligere erfaringer og pædagogik (Gilliam), og medlemmer af andelsboligforeninger reaktualiserer og omformulerer deres eksisterende værdier, så fællesskabet stadig fremhæves på et liberaliseret boligmarked, men i nye former (Bruun). Etnografien peger således på, hvordan politiske forsøg på at reformere velfærdsstaten producerer nye kontinuiteter frem for epokale brud. ${ }^{6}$

Når vi ser på tværs af bidragene til de to temanumre, er der meget, som tyder på, 1) at forandringer ikke erfares ens på tværs af velfærdsstatens institutioner, og 2) at velfærdsstaten og dens institutioner er kendetegnet ved „krydsende tidsligheder" og forskellige temporaliteter. Med krydsende tidsligheder mener vi, at forandringer foregår i forskellige og ofte modsatrettede tempi frem for i en lineær udvikling fra velfærdsstat til konkurrencestat. Vi er således ikke uenige med Pedersen (2011) i, at der er sket en forandring af den danske velfærdsstat, siden den blev lanceret som politisk projekt for mere end 60 år siden, men det er et empirisk og etnografisk spørgsmål, hvilke forandringer der er på spil, og hvordan folk skaber, erfarer og italesætter disse.

\section{(Velfærds)staten - som forestilling og krydsende konfliktlinjer}

For at nærme os forskellige folks og gruppers erfaringer af forandringer i velfærdsstaten må vi starte med at spørge, hvad staten er for en størrelse, og i denne sammenhæng særligt, hvordan danskere forstår velfærdsstaten som aktør eller mekanisme til at skabe sammenhæng, og hvilke forestillinger der knytter sig til velfærdsstaten. ${ }^{7}$ I antropologien har det været en vigtig pointe, at staten ikke kan iagttages som en helhed eller kan anskues fra ét strategisk analytisk udkigspunkt, men at staten udgør et kompleks af magtudøvelse, forskellige styringspraksisser og aktører, der ikke nødvendigvis fungerer med ét fælles rationale og formål. At det er notorisk svært at identificere staten (eller for den sags skyld velfærdsstaten), blev allerede påpeget af Radcliffe-Brown i hans berømte udsagn om staten som filosoffernes fiktion: „Staten eksisterer ikke i denne betydning i den fænomenale verden; det er filosoffernes fiktion" (Radcliffe-Brown 1940:xxiii). Mange antropologer har et grundlæggende kritisk og skeptisk blik på staten, måske fordi faget tidligere definerede sig selv ved at studere samfund, politik og magt uden stat (jf. Clastres 1987). I samme tradition sammenligner sociolog Phillip Abrams staten med en maske, i den forstand at det er en term, der ,skjuler den virkelige historie og undertrykkelse bag en ahistorisk maske, der er en legitimerende illusion" ([1977] 1988:77). ${ }^{8}$ Flere forfattere i nærværende temanumre af Tidsskriftet Antropologi 
argumenterer i samme tradition for, at den monolitiske velfærdsstat er en skrøne, og at staten snarere er et konglomerat af teknologier, aktører og praksisser, der konstant til- og afkobles hinanden. Dette betyder, at man ikke kan tale om staten som helhed eller én (ny type) stat.

I 1990'erne udkom der en bølge af antropologiske studier af staten. ${ }^{9}$ Akhil Guptas arbejde var skelsættende med „Blurred Boundaries“ (1995), hvor han rettede antropologiens søgelys mod „lokale bureaukratiers hverdagspraksisser og den diskursive konstruktion af staten i den offentlige kultur" (op.cit.375). Thelen, Vetters og Benda-Beckmann (2014) argumenterer for, at der reelt er to adskilte korpusser af litteratur og to typer studier af staten, som trænger til at blive forbundet med hinanden: på den ene side studier af ,interfaces“ (grænseflader) mellem borgere, embedsmænd og eksperter, oftest i statens periferier ( $\mathrm{fx}$ Long 1989), og på den anden side studier af kulturelle repræsentationer af staten (fx Hansen \& Stepputat 2001).

Førstnævnte type studier har i en dansk sammenhæng ofte været inspireret af Michael Lipskys (1981) arbejde med ,street-level bureaucrats“ eller frontlinjemedarbejdere, som i mødet mellem sagsbehandlere, klienter og minoriteter kropsliggør staten og dens politikker. Ligesom Thelen, Vetters og Benda-Beckmann (2015:56) påpeger, er denne type studier i Danmark vokset ud af en sektorbaseret anvendt antropologi, og med nogle nævneværdige undtagelser (Shore \& Wright 1997; Järvinen \& Mik-Meyer 2003; Jöhncke 2007; Shore, Wright \& Però 2011; Vaaben 2014) er de ikke blevet diskuteret samlet som etnografier om velfærdsstaten.

Hvad angår studier af kulturelle repræsentationer af staten, har Steffen Jöhncke fremhævet vigtigheden af livslang generaliseret reciprocitet for „Velfærdsstaten som integrationsprojekt“" (2007), mens Mikkel Rytter har påpeget, hvordan specifikke slægtskabsbilleder som fx ,familien Danmark“ knytter statens borgere sammen (Rytter 2007). Den danske velfærdsstat hænger sammen med danskernes forestillinger om samfundet som en naturligt eksisterende enhed og integreret helhed, hvor befolkningen er forbundet gennem fælles forestillinger og solidariske velfærdsordninger, der i sig selv er blevet en del af danskernes identitet og selvforståelse. Det kræver imidlertid bestemte former for deltagelse og samhørighed at være en del af fællesskabet, og de er de seneste årtier blevet udfordret af indvandring og andre former for globalisering. Ligesom Gullestad (1989, 1992b) peger både Jöhncke (2007) og Rytter (2007) på, hvordan eksklusions- og inklusionsmekanismer og grænsedragninger bidrager til opretholdelsen af forestillingen om en „,naturlig“ helhed.

I Konkurrencestaten skriver Pedersen (2011) på lignende vis om en bestemt opfattelse af forholdet mellem stat, samfund og økonomi, som han kalder „den samfundsøkonomiske forestilling“. Den er vokset frem sammen med vel- 
færdsstaten og er blevet en selvfølgelighed i den danske politiske debat. Den samfundsøkonomiske forestilling er ,en bestemt opfattelse af mennesket og dets motiver for at søge socialt samvær, men også en bestemt opfattelse af samfundet som et økonomisk eller organisk hele, hvor husholdningernes beslutninger anses for at have konsekvenser for statens, og hvor staten omvendt pålægges den opgave at skabe ligevægt, hvor markedet ikke kan « (op.cit.1718). Overgangen fra velfærdsstat til konkurrencestat er ifølge Pedersen markeret ved en overgang fra moralisme til økonomisme, det vil sige fra velfærdsstaten som et moralsk til et økonomisk projekt. Ud fra substantivistisk økonomisk antropologi er alle økonomiske systemer imidlertid også samtidig moralske; alle samfundsøkonomiske forestillinger er således både moralske og økonomiske. Dette er et centralt argument i Maja Hojer Bruuns artikel, der beskriver de sidste årtiers udvikling i den danske andelsboligsektor. Det forhold, at det i dag primært er økonomi, som definerer, hvem der kan få adgang til eftertragtede andelslejligheder i københavnsområdet, er i sig selv en moralsk økonomi, der af andelshaverne stadig omtales som et fællesskab, blot et økonomisk fællesskab med mere indskrænkede former for udveksling og gensidighed. Vi vil senere vende tilbage til, hvordan ideen om selvstændighed vinder frem i velfærdssamfundets moralske økonomi.

I forhold til de to korpusser af antropologisk litteratur om staten - staten som praksis og staten som forestilling - foreslår Thelen, Vetters og Benda-Beckmann (2014) en ,relationel antropologi om staten“, hvor antropologer skal være analytisk opmærksomme på „,boundary work“ eller grænsedragning. Grænsedragning er „den konstante forhandling af forestillinger om staten i og igennem sociale relationer, som også etablerer staten" (op.cit.8). Men hvor man i statskundskaben ofte betegner stat, marked og civilsamfund som forskellige sfærer, der styres efter forskellige principper, peger nyere forskning også på det særegne ved de skandinaviske stater: For det første var staterne administrative enheder allerede i tidlig moderne tid, før demokratiets indførelse, men havde dog en direkte relation til befolkningen via skatteopkrævning (Papakostas 2001). For det andet blev den særlige form for offentlig administration et historisk resultat af en sammenvævning mellem et relativt rationelt og upersonligt system - med en vis uafhængighed $\mathrm{i}$ forhold til både det politiske og „det civile“ liv - og de sociale bevægelsers (fx fagbevægelsens) repræsentation af grupper af menneskers kollektive interesser $\mathrm{i}$ forhold til staten (op.cit.38). Dette har betydet, at velfærdsstaten har kunnet optræde som noget upersonligt og upartisk, samtidig med at den kan gribe ind folks hverdag og personlige liv, uden at der sættes spørgsmålstegn ved dette.

I en skandinavisk sammenhæng har Halvard Vike (2015) bemærket, at stat og samfund typisk ikke ses som hinandens modsætninger. Han betvivler an- 
vendeligheden af bestemte forestillinger om stat og civilsamfund, som præger angelsaksisk og centraleuropæisk politisk filosofi. Vike fremhæver, at „det sivile samfunn i Norden knapt har eksistert. Størstedelen av det frivillige organisasjonslivet har aldri hatt som et viktig mål å stå utenfor staten, og fellesgodene de forvalter er som oftest en integrert del av statlig reguleringsog fordelingspolitikk. Organisasjonsformene har vært uhyre like og gjensidig kompatible« (op.cit.11). I de kulturelle forestillinger om velfærdsstaten er der ofte ikke nogen klar afgrænsning i forhold til samfundet som helhed. Richard Jenkins går så vidt som til at foreslå, at danskerne betragter staten som ,den gode nabo“" (Jenkins 2011:199).

I stedet for en analytisk opdeling i sfærer som stat, familie og civilsamfund foreslår Vike (2015) en tværgående analytik til at forstå forholdet mellem folks værdier og forestillinger om staten og de politiske institutioner og alliancer. Han understreger, at veIfærdsstaten skabes lokalt, og undersøger, hvordan statsmagten og effekten af nye policyinitiativer afstemmes og afbøjes lokalt af forskellige loyaliteter, interesser, værdier og alliancer mellem mennesker på tværs af roller og institutioner, i det han kalder „krydsende konfliktlinjer“. I de seneste år er der dog kommet en øget linjeledelse og mindre institutionel autonomi i Norge, og dette indebærer ifølge Vike større problemer med at afbøde de regler og procedurer, som ikke fungerer i praksis.

Fra et antropologisk perspektiv er der altså ikke tale om en ny type stat, men snarere at velfærdsstaten i nogen grad praktiseres på nye måder i en kamp om velfærdssamfundets goder, hvilket blandt andet giver sig udslag i reviderede mekanismer for inklusion og eksklusion. Hvis vi godtager ideen om, at velfærdsstaten skabes lokalt - det vil sige både i centraladministrationen, i konkrete offentlig-private samarbejder, i frivillige organisationer, i børnehaven og på bistandskontoret - kan man med rette spørge, om der ikke også er tale om forskellige måder at erfare og forstå forandring på, herunder hvor hurtigt folk oplever, at forandring sker. Dette vil vi vende tilbage til efter en diskussion først af spændingsfeltet mellem individ og fællesskab, dernæst af krydsende tidsligheder og acceleration samt slutteligt af nye mekanismer for inklusion og eksklusion. Disse er vores bud på tre centrale spændingsfelter, der indfanger konturerne af velfærdsstatens forandringsprocesser og belyser den samfundsmæssige diskurs om konstant forandring.

\section{Spænding mellem individ og fællesskab}

Ove Kaj Pedersen beskriver i Konkurrencestaten, at det enkelte menneske siden 1990 'erne i højere grad er gjort ansvarligt for sit eget liv. I velfærdsstatens tidsalder 
(1950-1990) var individet bærer af rettigheder, mens det i konkurrencestaten er den almindelige opfattelse, at mennesket først og fremmest bærer egne behov, som det har frihed til at realisere gennem rationelle, selvstændige og opportunistiske handlinger (Pedersen 2011:12). Hvor den danske velfærdsstats tiltag før skulle forme og sikre eksistensen af moralske medborgere, demokrati og fællesskab, betragtes borgerne i dag som personer, der med de passende incitamenter vil handle rationelt.

Antropologiske studier af de skandinaviske samfund peger på, at dette i nogen grad er en falsk modstilling. Mennesket er ikke enten socialt eller selvstændigt, moralsk eller opportunistisk. Der er ikke entydigt sket en bevægelse fra det ene til det andet, men der har gennem hele det 20. århundrede været en spænding og forskellige sammenkoblinger mellem disse træk. Den antropolog, som har vovet sig længst i en sådan karakteristik, er den norske Marianne Gullestad (1992a) med sin beskrivelse af en særlig norsk, og skandinavisk, modernitet. Hun beskriver en hel række spændingsforhold mellem forskellige værdier: mellem lighed og selvstændighed; mellem fællesskab og uafhængighed; mellem social involvering, prestige og dynamik på den ene side og tryghed, nærhed og stabilitet på den anden (op.cit.197). I dansk sammenhæng har studier også peget på spændinger omkring „rummelighed“ i betydningen inklusion og plads til forskellighed (Anderson 2008; Krøijer \& Sjørslev 2011). Egalitær individualisme er det begreb, Gullestad bruger til at udtrykke det forhold, at individet er ideologisk i forgrunden, mens den sociale helhed (samfundet og fællesskabet) udgør den baggrund, som ikke lader sig ignorere (Gullestad 1992a:183). Gullestad skriver: „At være et individ indebærer et ansvar over for og tilpasning til fællesskabets sociale regler og dermed en vis konformitet" (op.cit.198). Der er ikke tale om enten-eller, men forskellige konfigurationer af både-og - altså modsætningspar, der står i konstant relation til hinanden (se Strathern 2009).

Laura Gilliam sætter i sin artikel, „Nødvendighedens pædagogik. Optimeringskrav og det gode fællesskab i velfærdssamfundets skole“, spørgsmålstegn ved Konkurrencestatens tese om en stigende, ,individualisering“ i folkeskolen. Hun fremhæver, hvordan moralsk dannelse til fællesskab - at lære ,at være social“ fortsat er et vigtigt anliggende i folkeskolen. Gilliam karakteriserer snarere den nye udvikling som præget af standardisering og formalisering af de adfærdskrav, der stilles til den enkelte for at passe ind i samfundet. Oline Pedersen fremhæver i sin artikel, „Sundhedspleje, børnehave og konkurrencestat“, at individet længe har været formet af den anerkendende og kritiske pædagogik. Hendes feltarbejde blandt sundhedsplejersker på familiebesøg viser, at allerede nyfødte børn ,tages alvorligt" som individer, og at kravet om villighed til at arbejde med sig selv starter tidligt. En særlig form for ,individualisering“ er altså ikke et fænomen, som er 
kommet til Danmark med konkurrencestaten. Flere af tidsskriftets artikler viser, at det ikke er konkurrence individerne imellem, som betones i og af velfærdsstatens institutioner, men derimod kravet om forandring og selvstændighed.

Det centrale her synes at være, at den skandinaviske version af egalitær individualisme indebærer en særlig form for spænding mellem lighed og individualisme forstået som selvstcendighed. Mens ,,individualitet“ ifølge Gullestad ikke er noget positivt begreb som sådan, kan skandinavisk kultur alligevel beskrives som ekstremt individualistisk, fordi selvstændighed, uafhængighed, selvhjulpenhed og det at man kan „klare sig selv“"værdsættes meget højt (Gullestad 1992a:198). Flere antropologer og etnologer har trukket historiske linjer helt tilbage til bonde- og fiskersamfundet og peget på, at denne særlige form for individualisme er forbundet med „det fri liv" blandt selvejende fiskere og bønder. Her går selvstændighed, uafhængighed og det ,at kunne klare sig selv“ hånd i hånd med samhørighed og „et aktivt liv i fællesskab“, hvor man indgår i og kalder på fællesskabet i bestemte felter og til visse opgaver (Barnes 1954; Ekman 1991; Gullestad 1991; Korsgaard 2001, 2004; Lien 2001; Bruun 2011). Inger Anneberg og Nils Bubandts artikel, „Dyrevelfærdsstaten. Grisens krop, velfærdens historie og selve livets politik i Danmark“, giver et indblik i „det frie liv“ som landmand i dag. Stordrift i dansk svineproduktion er et erhverv $i$ benhård national og international konkurrence, og romantiske forestillinger om det frie liv dækker reelt over et hårdt arbejdsliv fyldt med kompromisser og bekymringer, hvor grisenes og landmændenes velfærd står i et spændingsforhold til hinanden.

Temanumrenes artikler viser også nye aspekter ved en anden af de spændinger, som Gullestad skrev om. Således afviser Katrine Schepelern Johansen og Julie Rahbæk Møller, at der skulle være sket en entydig bevægelse fra fællesskab og stabilitet til frihed og dynamik. Velfærdsstaten bygger grundlæggende på, at borgere kan hjælpes og skal udvikle sig. Kort sagt står øgede krav til individet ikke i et modsætningsforhold til at være indfældet i fællesskaber. Det lader snarere til, at det, som umiddelbart kan iagttages som øget individualisering, i lige så høj grad består i en standardisering, formalisering og synliggørelse af samfundets adfærdskrav til den enkelte. Disse krav om selvstændighed - som både indebærer $ø$ konomiske krav til at kunne „klare sig selv“, forventninger til uafhængighed og „at ville selv" samt stadig øget selvregulering og selvhjulpenhed - aftegner en ny balance mellem individ og fællesskab. Det nye består ikke som sådan i kravet om dynamik, men i standardisering, omhyggelig monitorering og synliggørelse af bestemte forandringsprocesser. Denne form for ,audit culture“ (revisionskultur) synes at have løsrevet sig fra det finansielle område og bredt sig til andre dele af institutionernes liv (Strathern 2000:2), hvilket ikke bare har sociale konsekvenser, men også konsekvenser for erfaringer af tid. 


\section{Krydsende tidsligheder og acceleration}

Jonas Frykman og Orvar Löfgren har i Den kultiverade människan (1979) argumenteret for, at middelklassens dannelse (mellem 1880 og 1910) indbefattede en ændret opfattelse af tid, herunder en ny opfattelse af sig selv som progressiv og med planer for fremtiden. ${ }^{10}$ For middelklassen, der i perioden som Frykman og Löfgren analyserer, blev tæt forbundet med det administrative lag i staten (se også Papakostas 2001), var „omgangen med tiden“ og det at planlægge for fremtiden et særligt kendetegn, som adskilte dem symbolsk og praktisk fra både bøndernes liv med årstidernes gang og overklassens lette og bekymringsløse liv. Med dannelsen af velfærdsstaten kom middelklassens modernitet til at repræsentere en ny normalitet, og middelklassens rationelle omgang med tiden blev gjort til et fælles anliggende og statslig politik. Med yderligere fremskrivning vil vi foreslå, at den moralske omgang med tiden inden for rammerne af velfærdsstaten stadig er udtryk for middelklassens værdier, både hvad angår fordømmelsen af de fattige og uvirksomme og glæden ved nye planlægningsværktøjer. ${ }^{11}$ For at have ret til velfærdssamfundets ydelser er det i dag endnu vigtigere end tidligere at være fuldtidsbeskæftiget eller i det mindste arbejds- eller uddannelsesparat og klar med en plan for jobsøgning og personlig udvikling. Glæden ved forandring, dynamik og selvudvikling er blevet stadig mere intens og ,et mål i sig selv - det vil sige noget, som alle må forholde sig til i deres hverdagsliv.

Velfærdsstaten har lige siden sin begyndelse været et socialt projekt, der har progression, forandring og dynamik som omdrejningspunkt. Velfærdsstaten er grundlagt på en idé om, at den skal skabe velstand for alle (Jöhncke 2007). Social forandring, dynamik og mobilitet er iboende velfærdsstatens institutioner på en sådan måde, at de fleste tiltag bør pege frem mod det fremtidige punkt, hvor de har gjort sig selv unødvendige. I vores samtid kan vi iagttage, at effekten af forskellige velfærdstiltag måles i forhold til denne indbyggede utopi, men at det samtidig indebærer, at de ønskede forandringer aldrig synes store eller hurtige nok, eller tilmed må betragtes som mislykkede. Dette gælder fx bekæmpelsen af arbejdsløshed, hvor denne ene plan for aktivering, arbejdsprøvning, etablering af akutjob m.v. afløser den anden uden at skabe fuld beskæftigelse, eller ved den tilsyneladende uendelige række af integrationsprojekter, der både karakteriserer en konkret proces og forandring af nyankomne og et endemål og en samfundsmæssig ideal tilstand (jf. Olwig \& Pærregaard 2011). Denne dynamik er beskrevet som et „transformationens tyranni“ (Clarke \& Newman 1997) og virker gennem en hegemonisk diskurs, der på en og samme tid legitimerer, naturaliserer og nødvendiggør ændring og fornyelse. Det er således ikke blot sproget, men også selve ideen om forandring, der er i forandring. Tilsvarende beskriver Halvard Vike i „Utopian Time and Contemporary Time“ (2013) et skift i velfærdsstatens 
tidsorientering fra „utopisk tid“ - forstået som en tidslig horisont, hvor alle kollektivt arbejder frem mod en række mål, som motiverer og indgyder håb på en sådan måde, at folk er villige til at ofre noget på vejen til gavn for en bedre fremtid - til ,samtidig tid,“ forstået som en markedstid, hvor der forventes forbedringer her og nu (op.cit.36-37). ${ }^{12}$

I flere af artiklerne $i$ de to temanumre finder vi imidlertid tidslige orienteringer mod fremtiden, som indebærer en ny slags utopisk tid. Karen Lisa Salamon, Simon Lex og Torbjörn Friberg beskriver i deres artikel, „Konvergens på tværs af velfærdsstaten“, et nyt fænomen i velfærdsstatens udvikling, nemlig den såkaldte funktionskonvergens. Konvergens opstår, når forskellige parter eller funktioner smelter sammen i nye multifunktionelle enheder: posten, som nu skal servicere borgerne bredt og fx bringe medicin ud, universiteterne, som foruden forskning og uddannelse skal skabe vækst og innovation, samt biblioteker, som også er kulturhuse og yder borgerservice. Denne tendens skal skabe større fleksibilitet, omkostningseffektivitet og øget produktivitet ved at efterligne forhold på det private marked. Konvergens og offentlig-private partnerskaber, hvor effekten af offentlige midler menes at kunne mangedobles i samspil med private midler, er en form for magisk tænkning, hvor helheden er mere end summen af delene. Denne tænkning indebærer også en tidslig figur, nemlig forventningen om, at et sammenløb vil intensivere og accelerere forandring. Den øgede produktivitet og de evige reformer af det offentlige system giver kun mening, hvis man stadig ser dem i lyset af den oprindelige målsætning om velfærd til alle i fremtiden. Det offentlige skal „,vækste sig ud af krisen“ eller få mere ud af mindre (jf. Vaaben 2014).

Konvergenstænkningen minder om det, som Jane Guyer (2007) beskriver som „det langsigtede perspektiv“ i makroøkonomisk planlægning. Hvor økonomisk politik i den vestlige verden i efterkrigsårene fokuserede på genopbygningen af samfundene i det korte perspektiv, er neoliberal og monetaristisk tænkning i dag orienteret mod det lange perspektiv, hvor frie markeder vil skabe vækst og med tiden regulere sig selv. I dansk sammenhæng giver det sig fx udslag i modellen DREAM (Danish Rational Economic Agent Model), der er udviklet med det formål at forudsige de langsigtede effekter af forskellige økonomiske tiltag. ${ }^{13}$ Eksempelvis anbefalede modellen af hensyn til de langsigtede effekter for beskæftigelsen at forøge arbejdsudbuddet i begyndelsen af 2010'erne, til trods for at man på det tidspunkt befandt sig i en periode med høj arbejdsløshed. Imens makroøkonomisk tænkning forholder sig ,profetisk“ og „evangelisk“ til det langsigtede perspektiv, er der ifølge Guyer (2007) sket en „tømning af den nære fremtid“. Klassisk planlægning af den umiddelbare, nære fremtid er blevet erstattet af ,afbrudt tid“ (punctuated time) med tidsstyring gennem benchmarks, 
terminer og kvartalsregnskaber. Nutiden reduceres på denne måde til en række situationer, begivenheder og datoer, som skal „håndteres“ (op.cit.416). ${ }^{14}$

Der synes med andre ord at være flere tidsligheder på spil i velfærdsstaten, men disse er ulige fordelt. Med afsæt i Halvard Vikes idé om krydsende konfliktlinjer (Vike 2015) vil vi tale om krydsende tidsligheder med det formål at beskrive tidslighedernes landskab i velfærdsstaten. I centraladministrationen og blandt andre policyudviklere drives nye ændringer og tiltag frem med stadig større hastighed, og forandring er blevet en positiv værdi i sig selv. Samtidig registrerer andre aktører i velfærdsstaten ikke, at der sker nogen nævneværdig ændring. I Laura Gilliams artikel afbøder og omskaber skolelærere de utilsigtede konsekvenser af politiske tiltag, og hos Salamon, Lex og Friberg har medarbejderne i de organisationer, som skal konvergere, deres egne måder at gøre tingene på. Der er afstand mellem styringslogikkernes idealer og den faktiske, daglige praksis, og når medarbejderne hos postvæsenet forsøger at „regne baglæns“ fra den forestillede fremtid til nødvendige handlinger i nutiden, er resultatet ikke nødvendigvis innovation, men reproduktion af eksisterende organisationsstrukturer. Et noget anderledes eksempel kan ses i universiteternes langsigtede mål om internationalisering og optag af flere udenlandske studerende på deres uddannelser. Ifølge Lisanne Wilken og Mette Ginnerskov Hansens artikel om internationale studerende i Danmark, som oplever, at de danske studerende ikke har særlig megen omgang med eller interesse for deres udenlandske medstuderende, udebliver den planlagte internationalisering i praksis.

Set fra politikernes, centraladministrationens og policyudviklernes perspektiv er fremtidssikringen af velfærdsstaten betinget af medarbejdernes, borgernes og brugernes villighed til at udvise dynamik, foretagsomhed og konstant „newness". I bogen Alienation and Acceleration (2010) peger sociolog Hartmut Rosa på acceleration som særkende ved den aktuelle senmodernitet. Øget tempo og acceleration findes $i$ både arbejdslivet og de intime sociale relationer, $i$ digitalisering, på de finansielle markeder og i politiske beslutningsprocesser. Nina Vohnsen beskriver i sit bidrag, „Evidensbaseret politikudvikling. Brudflader mellem forskning og bureaukrati", hvordan en embedsmand i centraladministrationen ,"lige fik skrevet ti nye forslag over en kop te“. Hendes artikel beskriver, hvordan embedsmændenes arbejdspraksis tilsidesætter tid til eftertænksomhed og offentlig debat, mens kontrakter og nye strategiske tiltag skifter med lynets hast, ofte motiveret af politikernes eller embedsmændenes behov for at håndtere konkret kritik eller udvise passende handlekraft her og nu. ${ }^{15} \mathrm{I}$ lyset af de etnografiske bidrag i de to temanumre er det væsentligt at spørge, om det langsigtede perspektiv og den samtidige acceleration skaber større effekt eller blot mere tomgang? 
Ifølge Rosa fører accelerationen uvægerligt til stigende udbrændthed, stress og fremmedgørelse blandt mennesker. ${ }^{16}$ Selv om vi ikke nødvendigvis deler Hartmut Rosas sammenknytning af acceleration og fremmedgørelse med dette begrebs indbyggede normativitet og generalisering, er det påfaldende, at statens frontmedarbejdere og brugerne af de nye offentlige „servicetilbud“ ofte ikke forstår meningen med de krav om forandring, som de kontinuerligt pålægges. Dette misforhold er i Johansen og Møllers artikel, „Spændingsfeltet mellem dynamik og stabilitet. Udvikling og behandling af mennesker med sindslidelser i det danske velfærdssamfund“, sat på spidsen og personificeret af den skizofrene misbruger Thomas Jensen. Hverken han eller hans behandlere forstår, hvorfor han „skal udfases“ af sin nuværende behandling. I Københavns Kommunes socialforvaltning blev Forandringskompasset indført i som et „effektstyringsredskab“, men i praksis blev proceduren ofte meningsløs, fik uønskede effekter, og ingen kunne forklare, hvordan embedsmændene brugte det, eller hvad de økonomiske konsekvenser var.

Der er forskellige tidslige orienteringer og erfaringer af forandring på spil hos velfærdsstatens forskellige aktører, og forandring udfolder sig i forskellige, nogle gange modsatrettede, tempi. Spørgsmålet er, hvad der er effekten af de krydsende tidsligheder, og hvad det betyder for, hvem der står inden for og uden for det kollektive velfærdsprojekt.

\section{Inklusion/eksklusion: velfærdsstaten som „begrænset gode“}

Historikeren Søren Mørch harbeskrevet velfærdsstaten somet inkluderende projekt, der favnede hele befolkningen og sigtede mod at løfte alle ind i velstand - bedst indfanget med sloganet „Danmark for folket“ ${ }^{4}{ }^{17}$ Mange samfundsvidenskabelige studier har imidlertid påpeget, at velfærdsstatens inklusionsprojekt også altid har indeholdt en række eksklusionsmekanismer. Antropologer har beskrevet, hvordan kulturelle værdier såsom lighed forstået som enshed (Gullestad 1992a) har fungeret som en særlig mekanisme til at skelne imellem dem, som står henholdsvis inden for og uden for samfundets forskellige fællesskaber (fx Olwig, Larsen \& Rytter 2011). Flere artikler i de to temanumre peger imidlertid på, at borgernes evne til at imødekomme forventningen om selvstændighed, selvudvikling og et aktivt liv udgør en ny mekanisme for inklusion og eksklusion, der føjer sig til ideen om kulturel enshed.

De etnografiske analyser afinklusions-og eksklusionsmekanismer skal sammenholdes med en anden udvikling i den danske velfærdsstat: Hvor velfærdsstaten blev skabt under økonomisk opsving i efterkrigstiden - det kendte slogan var, ,,at få har for meget og færre for lidt"“ - er der i de senere år opstået en diskurs om 
økonomisk „knaphed“ på velfærdsydelser. Den offentlige debat er kommet til at handle om, hvordan velfærdsydelserne skal fordeles, og om ydelserne stadig bør være for alle: Skal nyligt ankomne flygtninge have adgang til de samme universelle ydelser som borgere, der er født og opvokset i landet? Er „dovne Robert“ og ,fattig-Carina“ lige så berettiget til at modtage offentlige ydelser som de, der er villige til at tage et arbejde eller ikke bruger penge på cigaretter?

Denne udvikling kan begribes med teorien om begrænsede goder. George Foster (1965) introducerede begrebet ,limited good“ $i$ et klassisk feltarbejdsbaseret studie fra Mexico til at beskrive en model for økonomisk tænkning i traditionelle bondesamfund. Ifølge Foster oplevede hans informanter at leve i en verden med knappe ressourcer, hvor der følgelig var en stadig konkurrence om goderne, misundelse og skiftende alliancer mellem beboerne. Fosters økonomiske teori om begrænsede goder tenderer således mod et nulsumsspil. Man kan sige, at velfærdsstaten og dens ydelser opleves og italesættes af mange som et begrænset gode hvis nogle borgere modtager goderne, er der mindre til andre.

Lisanne Wilken og Mette Ginnerskov Hansens artikel, ,Internationalisering og ulighed på videregående uddannelser i Danmark“", afspejler aktuelle diskussioner i den danske offentlighed om „velfærdsturisme“, og hvem der skal have del i velfærdsstatens ydelser, i forhold til en analyse af udenlandske studerendes forhold på danske universiteter. Hvor international mobilitet offentligt italesættes som et middel til at forfølge egne muligheder, oplever mange udenlandske studerende i Danmark isolation og social udstødelse i et studiemiljø, hvor de danske studerende med deres økonomiske råderum og svingende flid virker forkælede og dovne.

Inger Anneberg og Nils Bubandt bruger i deres artikel, „Dyrevelfærdsstaten. Grisens krop, velfærdens historie og selve livets politik i Danmark“, dyrevelfærd som en analogi til at pege på de eksklusionsmekanismer, der løbende tager form, selv når velfærd skabes som et tilsyneladende inkluderende projekt. Gennem dyrevelfærd er produktionsdyr blevet genstand for statslig styring og forsorg, og dyrene er - ligesom borgerne - blevet skabt som bestemte konfigurationer: Nogle dyr må ofres, så andre dyr kan få flere rettigheder. En tilgang inspireret af studier af videnskab og teknologi (STS) gør det muligt at fremanalysere modsætningerne mellem velfærd og profit, selvbestemmelse og „governmentality“, inklusion og eksklusion, som ikke kun strukturerer landbruget, men også velfærdsstaten af i dag.

I forhold til opbygningen af det danske velfærdssamfund og dets institutioner er deltagelse på arbejdsmarkedet en vigtig markør og inklusionsmekanisme. ${ }^{18}$ I Danmark er pligten til at arbejde grundlovsfæstet sammen med sondringen mellem den arbejdsduelige og den ikke-duelige borger (Pedersen 2014). ${ }^{19}$ Danske borgere kan ikke uden videre „melde sig ud“ af det danske arbejdsmarked, 
medmindre man ikke er i stand til at udføre et arbejde; så har man til gengæld ret til at blive forsørget af det offentlige. Dette afspejler sig i Bodil Ludvigsens artikel, „Når ældre mennesker bliver gamle. Betydningen af velfærdsstaten og medborgerskabet", hvor de gamle kan „trække ældrekortet" og dermed har mulighed for at trække sig ud af arbejdsmarkedets ret-og-pligt-relation, uden samtidig at blive helt ekskluderet af samfundet. Det er en interessant observation, at de forventes fortsat at gøre en aktiv indsats for at holde sig i gang, tage deres medicin og efter bedste evne pleje deres krop, selv om de ikke længere er del af arbejdsmarkedet. Man kan sige, at inklusion i samfundet gennem deltagelse på arbejdsmarkedet udvides til et bredere krav om kropslig aktivitet, engagement og villet selvstændighed for at have legitim adgang til ydelser som pension, der tidligere blev set som „passiv forsørgelse“. Noget tyder på, at „passiv forsørgelse“ er på vej ud af velfærdssamfundet. I Johansen og Møllers artikel, „Spændingsfeltet mellem dynamik og stabilitet. Udvikling og behandling af mennesker med sindslidelser i det danske velfærdssamfund“, skal psykisk syge, som tidligere ,på godt og ondt" blev opbevaret i anstalter og på forsorgshjem nu inkluderes og leve op til samfundets krav om dynamik og selvudvikling.

Nina Vohnsens artikel, „Evidensbaseret politikudvikling. Brudflader mellem forskning og bureaukrati“, vidner om vigtigheden af ,,aktivitet" $i$ forhold til inklusion, og om, hvor høj politisk prioritet det har at få folk på sygedagpenge tilbage på arbejdsmarkedet igen. Artiklen beskriver forsøget „Aktive - hurtigere tilbage“, hvor folk tilskyndes til at være aktive under deres sygdom, så de kan komme hurtigere tilbage til arbejdsmarkedet. Endelig viser Oline Pedersen i sin artikel, „Sundhedspleje, børnehave og konkurrencestat?“", hvordan moralsk ansvarlige forældre forventes at lave diverse aktiviteter med henblik på at stimulere deres babyer, så de nyfødte ikke sakker bagud i udviklingstrin. Senere trænes børn i selvbevidsthed, selvkontrol og selvrefleksion. De bliver således gjort bevidste om, at de besidder et udviklingspotentiale.

Det overlades med andre ord ikke til tilfældighederne, om og hvordan ældre, psykisk syge, sygemeldte og småbørn udvikler sig og udviser kropslig aktivitet. En lang række redskaber - og andre måder at skabe evidens for udvikling på - er udviklet til at måle fremskridtene og tilskynde folk til at udvikle sig, være aktive og blive en accepteret del af samfundet. Samtidig italesættes ressourcerne i det danske velfærdssamfund i stigende grad som et begrænset gode, og det diskuteres, hvordan disse skal fordeles. Disse forhold skaber nye konfigurationer af inklusion og eksklusion..$^{20}$ Velfærdsstatens krav om at ,være med på forandringer“ og være indstillet på tempoet, hvormed de introduceres, er blevet en ny grænsedragning, der føjer sig til portvagtsbegrebet om „lighed som (kulturel) enshed“. 


\section{Konklusion}

I denne indledning har vi udforsket artikelbidragenes forskellige bud på, hvordan værdier, omgangsformer, individ- og fællesskabsopfattelser ændrer sig, i takt med at den danske velfærdsstat og dens virke antager nye former. Dertil kommer en interesse for, hvordan forandring og dynamik er et politisk anliggende, som i sig selv må underkastes etnografisk undersøgelse.

Temaet om velfærdsstaten var oprindelig ansporet af en undren over det tilsyneladende misforhold mellem den regionale etnografi, der har kredset om begreber som lighed, enshed, fællesskab og egalitær individualisme, og Ove Kaj Pedersens (2011) beskrivelse af overgangen til en ny type stat kendetegnet ved internationalisering, konkurrence og optimering af borgerne, som i stigende grad søger at realisere egne behov. Ved at „kigge ind i institutionerne“ ønskede vi at diskutere, i hvilket omfang Pedersens diagnostik viser sig i etnografiske studier, og hvorvidt der er sket et skred i centrale værdier, så antropologer må forkaste eller videreudvikle gældende portvagtsbegreber i den skandinaviske regionale etnografi.

Disse spørgsmål svarer temanumrene ikke udtømmende på, men forfatterne kommer med en række vigtige bud på, hvordan nye reformer, styringsværktøjer og -logikker påvirker samfundets moralske økonomi. Selvstændighed, dynamik og forandringsparathed er ikke bare abstrakte kendetegn ved en ny type stat, men virker som mekanismer til at sondre mellem dem, som bør have del af de fælles goder, og dem, som ikke bør. Når bondesamfundets, og senere velfærdsstatens, forestillinger om „begrænsede goder“ føres videre, skabes ikke alene mistro, mistillid og misundelse, men også nye mekanismer for inklusion og eksklusion.

Når man ser på de tre udviklinger - 1) spændingsfeltet mellem individ og fællesskab, der giver sig udslag i en fornyet betoning af selvstændighed og selvudvikling, 2) acceleration og krydsende tidsligheder, hvor øget dynamik skaber en, nærmest magisk, forventning om at få mere ud af mindre, samt 3) samfundets inog eksklusionsmekanismer i lyset af forestillinger om velfærd som et begrænset gode - peger de tilsammen frem mod et polariseret samfund, et samfund, der er splittet mellem dem, der er del af arbejdsmarkedet og udviser passende selvstændighed, og dem, der ikke har arbejde eller ikke ,udviser tilstrækkeligt initiativ" til at indgå i arbejdsmarkedets ret-og-pligt-relation. Hvor velfærdsstaten sigtede mod at udligne forskelle via omfordeling, drives forandringsstaten frem af en eksklusiv solidaritet med en fortsat udgrænsning af de grupper, der er „gået i stă“" - såsom hjemløse, arbejdsløse, sindslidende, stressede, handicappede, misbrugere, flygtninge og beboere i udkantskommuner. Frem for at fokusere på en stigende individualisering og konkurrence har vi beskrevet, hvordan fordringen 
om selvstændighed er blevet forstærket og virker som forudsætning for at deltage i samfundets fællesskaber og opnå anerkendelse og livsmuligheder.

Som alternativ til begrebet konkurrencestat har vi foreslået begreberne forandringsstaten og selvstændighedssamfundet. Forandringsstaten er en dynamisk stat, der er kendetegnet ved, at forandring ikke blot er et middel til at opnå et højere mål om bedre velstand for alle, men er blevet mål i sig selv. Forandring er på én gang statens etos og selve genstanden for de statslige politikker. Ideen om forandringsstaten kan samtidig åbne for videre undersøgelser af forskellige forestillinger om forandring, og hvordan disse i sig selv er i opbrud. Det er svært, men nødvendigt for antropologer, der laver etnografiske studier af deres eget samfund, at underkaste begreber som forandring, som er en højt skattet kulturel værdi, et distanceret antropologisk blik.

Selvstændighedssamfundet beskriver den moralske økonomi, der ligger til grund for forandringsstaten. Pedersen (2011) beskriver en overgang fra moralisme til økonomisme - men økonomismen indebærer også en bestemt moralitet om selvstændighed og evne til at klare sig selv, som artiklerne tegner konturerne af. Dette er forventninger, som ikke entydigt kommer udefra eller oppefra, men som den enkelte også indoptager og forventer af sig selv. Selvstændighed indebærer en særlig, ofte uudtalt, balance mellem individ og fællesskab med rødder tilbage til bonde- og fiskersamfundets idealer om selvbestemmelse og økonomisk uafhængighed, men som er blevet tilføjet nyere ideer om modenhed - evnen til at kunne tænke, føle og handle tilsyneladende uafhængigt af andre samt stå i opposition til autoriteter - og selvstyring i forhold til at træffe tilsyneladende frie valg og lægge planer for fremtiden.

\section{Noter}

Tak. Vi er taknemmelige for de mange kommentarer og konstruktive forslag til forbedringer, som vi fik fra deltagerne ved det såkaldte „Kitchen table seminar“ på Moesgaard den 20. maj 2015, hvor vi præsenterede de første ideer til denne indledning. Tak til Halvard Vike, Steffen Jöhncke, Hanne Veber, Dorthe Brogård Kristensen samt Julie Rahbæk Møller for at læse og kommentere på forskellige udgaver af denne indledning.

1. Esping-Andersens (1990) andre to velfærdsmodeller er henholdsvis den såkaldte liberale, begrænsede velfærdsmodel, hvor økonomisk understøttelse alene sker i enkelte tilfælde, fx ved massiv fattigdom. Denne model kendes i forskellige variationer i fx USA og Storbritannien. Dernæst findes den konservative, korporative velfærdsmodel, hvor familieinstitutionen tildeles et stort ansvar, og hvor borgerne må have udvidede forsikringsordninger. Denne model kendes blandt andet fra Tyskland.

2. Begrebet ,politisk kultur“" opstod i 1960 'ernes USA i feltet mellem antropologi og statskundskab (Pye \& Verba 1965 i Togeby 1987) og omfatter således fællesskaber, kollektive værdier og ræsonnementer, der praktiseres i mange forskellige sociale sammenhænge. 
3. Denne pointe er særligt kommet frem i studier af danskernes forhold til flygtninge og indvandrere (Olwig, Larsen \& Rytter 2012).

4. Den tidligere socialdemokratiske regerings (2011-2015) beslutning om at frasælge aktier i det danske energiselskab DONG i 2014 er et illustrativt eksempel på en proces, hvor forestillingen om konkurrence, tilpasning og fleksibilisering antages at sikre selve grundlaget for fremtidens velfærdsstat.

5. Diskussioner af forandringen af velfærdsstaten i dag er på mange måder parallelle med interessen for globalisering og globale forandringsprocesser i antropologien i 1990'erne (Gupta \& Ferguson 1997; Hannerz 1989; Friedman 1994). Hvor antropologer tidligere havde været bekymrede for, „,at der ikke ville være noget tilbage at studere“, når kolonialisme, kapitalisme, kristendom og anden kulturel påvirkning havde gjort en ende på verdens mangfoldighed, pegede en række nye studier af global cirkulation af mennesker, varer og ideer dengang på, at den øgede udveksling ikke umiddelbart førte til større kulturel og social ensretning eller enshed (Appadurai 1996; Wilk 1999; Gaonkar \& Povinelli 2003). Studierne viste, at der ikke var tale om simpel påvirkning, men at mennesker i mødet med nye økonomiske, politiske og kulturelle strømninger formulerer nye identiteter og udvikler nye former for kultur og økonomisk udveksling.

6. For knap ti år siden påpegede Joel Robbins (2007), at antropologer har en tendens til at fremhæve kulturel kontinuitet og analytisk at udgrænse diskontinuitet og brud. Robbins' hypotese var, at antropologer bevidst eller ubevidst afviser, at kultur sådan lige står til at forandre, til trods for at forandring i nogle sociale fællesskaber og sammenhænge må betragtes som en dominerende idé. Blandt kristne konvertitter i Papua Ny Guinea, hvor Robbins har gennemført sit feltarbejde, er radikal forandring, diskontinuitet og brud en indgroet del både af hverdagslivet og af synet på fremtiden. Folk mener, at de lever et nyt liv, eller at de potentielt lever et helt andet liv $\mathrm{i}$ morgen. I det lys argumenterer Robbins for, at der er behov for at tænke over, hvordan folk erfarer og praktiserer forandring samt forholder sig til nye ideer og brud.

7. Andre antropologer har i de senere år beskæftiget sig med begrebet velfærd, herunder også former for velfærd eller ,well-being“, som ikke udgår fra staten eller er forbundet med statslige institutioner og deres virke (Edgar \& Russel 1998; Corsín Jiménez 2008; Langer \& Højlund 2011; Gulløv \& Højlund 2015).

8. I en nyere analyse af den danske velfærdsstats omfattende interventioner i udsatte palæstinensiske flygtningefamilier bosat i Gellerupparken i Aarhus foreslår Mette-Louise Johansen (2013) tilsvarende, at vi kan begribe og analysere den danske stats fremtrædelsesformer som havende fem forskellige ansigter afhængigt af situationens konkrete mål og midler. Johansen diskuterer således „,the trust-me state“, „the uncertain state“, „the trickster-state“, „, the prying state“ og ,the police-state“.

9. Mange antropologiske studier af staten omhandler krig, overvågning, tvang og den umiddelbart synlige del af statens magtanvendelse, men efterhånden som flere antropologer har vendt blikket mod moderne velfærdssamfund, er der også kommet flere studier af bureaukrati og velfærdsydelser.

10. Dette skal ses i forlængelse af Max Webers udlægning af Den protestantiske etik og kapitalismens ånd (1995 [1904]), hvor han peger på den protestantiske arbejdsetik med dens særegne kombination af nøjsomhed og et positivt syn på hårdt arbejde og verdslig akkumulation.

11. Velfærdsstaten og dens modernisme har dog set flere modbevægelser gennem tiden, hvor mennesker eller sociale grupper har følt sig hægtet af, selv har valgt at „koble sig af ræset“ eller blot drømmer om et langsommere liv. Dette italesættes fx for tiden i den offentlige debat som udfordringerne $\mathrm{i}$,udkantsdanmark“.

12. Tilsvarende påpeger historiker Michael Böss i Det demente samfund. Historieløshed $i$ nutidskulturen (2014), hvordan samtidens her-og-nu-fokus på aktuelle begivenheder leder $\mathrm{i}$ retning af en stat og et samfund, der mister sin historiske hukommelse og følgelig ikke kan tage ved lære af fortidens fejltagelser. 
13. Modellen er baseret på ideen om, at mennesker udviser rationel økonomisk adfærd, og dannede blandt andet grundlag for Velfærdskommissionens arbejde, der blev nedsat i 2003 i Anders Fogh Rasmussens regeringstid og skulle komme med anbefalinger til sikring af et „velfungerende velfærdssamfund i fremtiden“" og skitsere „nødvendige“ reformer.

14. Dette bringer Robbins' spørgsmål om antropologers villighed til at beskrive bestemte former for forandring ind igen. Antropologer har haft en tendens til at beskrive forandring med metaforer taget fra lineære tidsopfattelser - som flow, flux og proces - hvilket har den slagside, at antropologien som disciplin har vanskeligt ved at teoretisere radikal forandring og diskontinuitet (Robbins 2007:11-12).

15. Journalist Jesper Tynell viser i Mørkelygten - embedsmoend fortceller om politisk tilskcering af tal, jura og fakta (2014), at embedsfolk fra diverse ministerier i flere sager over de senere år på baggrund af personlige ambitioner eller politisk pres oppefra har præsenteret tal og fakta til offentligheden på en måde, så de reelt bliver uforståelige og svære at efterprøve for andre aktører.

16. En tilsvarende diagnose har i dansk sammenhæng fået psykolog Svend Brinkmann (2014) til at udgive en antiselvhjælpshåndbog, hvor han råder læserne til at ,stå fast" ved blandt andet at fyre deres coach og læse romaner i stedet for selvhjælpsbøger.

17. Mørch påpeger dog også, at velfærdsstaten oprindeligt var et nationalt projekt, der sigtede mod at forhindre social uro, konflikt og regulær borgerkrig (Mørch 2003:74-75 i Jöhncke 2007: $51)$.

18. Økonom Guy Standing $(2011,2014)$ har foreslået, at vi på globalt plan ser konturerne af en ny international klasse, et såkaldt ,prekariat“, der netop er kendetegnet ved, at de ikke kan få fæste på arbejdsmarkedet i den neoliberale økonomi, uagtet deres i nogle tilfælde høje uddannelsesniveau og forskellige løfter fra skiftende regeringer. Prekariatet er ifølge Standing en ny klasse, der tager form på tværs af klassiske marxistiske opfattelser af industrisamfundets klasser og omfatter både arbejdsmigranter, timeansatte, løsarbejdere samt korttids- og projektansatte, som havner i en permanent oplevelse af at være afkoblet fra de livsmuligheder, der er andre forundt.

19. Ove Kaj Pedersen beskriver i bogen Markedsstaten (2014) baggrunden for velfærdsstaten og opbygningen af det danske arbejdsmarked. Grundlovens $§ 75$ af 1849 sikrede, at ,den, der ikke selv kan ernære sig eller sine, og hvis forsørgelse ikke påhviler nogen anden, er berettiget til hjælp i det offentlige, dog mod at underkaste sig de forpligtelser, som loven herom påbyder". Pligten til selvforsørgelse og det offentliges forpligtelse til at forsørge den, der ikke kan forsørge sig selv, har været koblet sammen siden reformationen. Det betyder ifølge Pedersen, at grundloven videreførte en arbejdspligt. De danske politiske debatter om dagpenge, og at danskerne skal arbejde tidligere, mere og længere, er utænkelige i England og USA, hvor borgerne har ret til at tage et arbejde, men ikke pligt (Pedersen 2014:54).

20. Et aspekt ved forandringsstaten, som vi slet ikke har beskæftiget os med i denne indledning, er den stadig større registrering, overvågning og kontrol af borgerne på alle niveauer af stat og samfund (Lauritsen 2011): digitaliseret borgerservice, kameraovervågede boligområder, netværksbaserede elektroniske kalendere, hvor chefen kigger én over skulderen, og folkeskolens elevplaner og kommunikationsportaler, hvor både elevers, forældres og læreres indsats kan monitoreres. Omfanget af overvågningsteknologier tager også form af en sikkerhedsstat, der retter sit upersonlige. men allestedsnærværende blik mod alt fra potentielle børnelokkere og skattesnydere til medborgere, der måske kan udvikle sig til radikaliserede terrorister (jf. Krøijer 2013; Rytter \& Pedersen 2014). 


\section{Litteratur}

Abrams, Philip

1988 Notes on the Difficulty of Studying the State. Journal of Historical Sociology 1(1): 58-89.

Anderson, Sally

2008 Civil Sociality: Children, Sport, and Cultural Policy in Denmark. Charlotte, NC: Information Age Publishing.

Appadurai, Arjun

1986 Theory in Anthropology: Center and Periphery. Comparative Studies in Society and History 28(2):356-61.

1996 Modernity at Large. Cultural Dimensions of Globalization. Minneapolis: University of Minnesota Press.

Barnes, John A.

1954 Classes and Committees in a Norwegian Island Parish. Human Relations 7:39-58.

Brinkmann, Svend

2014 Stå fast. Et opgør med tidens selvudviklingstrang. København: Gyldendal Business.

Bruun, Maja Hojer

2011 Egalitarianism and Community in Danish Housing Cooperatives. Proper Forms of Sharing and Being Together. Social Analysis 55(2):62-83.

Bruun, Maja Hojer, Gry Skrædderdal Jakobsen \& Stine Krøijer

2011 Introduction. The Concern for Sociality. Practicing Equality and Hierarchy in Denmark. Social Analysis 55(2):1-19.

Böss, Michael

2014 Det demente samfund: Historieløshed i nutidskulturen. København: Kristeligt Dagblads Forlag.

Clarke, John \& Janet Newman

1997 The Managerial State: Power, Politics and Ideology in the Remaking of Social Welfare. London. Sage Publishing.

Clastres, Pierre

1987 Society Against the State: Essays in Political Anthropology. New York: Zone Books.

Corsín Jiménez, Alberto (ed.)

2008 Culture and Well-Being: Anthropological Approaches to Freedom and Political Ethics. London: Pluto Press.

Edgar, Iain R. \& Andrew Russell

1998 The Anthropology of Welfare. London: Routledge.

Eisenstadt, Shmuel Noah

$2000 \quad$ Multiple Modernities. Dædalus 129(1):1-29.

Ekman, Ann-Kristin

1991 Community, Carnival and Campaign: Expressions of Belonging in a Swedish Region. Stockholm: Stockholm Studies in Social Anthropology. 
Englund, Harri

1996 Witchcraft, Modernity and the Person: The Morality of Accumulation in Central Malawi. Critique of Anthropology 16(3):257-79.

Esping-Andersen, Gøsta

1990 The Three Worlds of Welfare Capitalism. Cambridge: Polity Press.

Foster, George

1965 Peasant Society and the Image of the Limited Good. American Anthropologist 67(2): 293-315.

Friedman, Jonathan

1994 Cultural Identity and Global Process. London: Sage.

Frykman, Jonas \& Orvar Löfgren

1979 Den kultiverade människan. Lund: LiberLäromedel.

Gaonkar, D.P. \& Elizabeth Povinelli

2003 Technologies of Public Forms: Circulation, Transfiguration, Recognition. Public Culture 15:385-97.

Gullestad, Marianne

1989 Small Facts and Large Issues: The Anthropology of Contemporary Scandinavian Society. Annual Review of Anthropology 18:71-93.

1991 The Transformation of the Norwegian Notion of Everyday Life. American Ethnologist 18(3):480-99.

1992a Egalitarian Individualism. In: M. Gullestad: The Art of Social Relations. Essays on Culture, Social Action and Everyday Life in Modern Norway. Pp. 183-200. Oslo: Scandinavian University Press.

1992b Symbolic Fences. In: M. Gullestad: The Art of Social Relations. Essays on Culture, Social Action and Everyday Life in Modern Norway. Pp. 165-182. Oslo: Scandinavian University Press.

Gulløv, Eva \& Susanne Højlund

2015 At fare vel. Antropologiske refleksioner over velfærd. Jordens Folk 50(1-2):44-51.

Gupta, Akhil

1995 Blurred Boundaries: The Discourse of Corruption, the Culture of Politics and the Imagined State. American Ethnologist 22(2):375-403.

Gupta, Akhil \& James Ferguson (eds)

1997 Culture, Power, Place: Explorations in Critical Anthropology. Durham \& London: Duke University Press.

Guyer, Jane I.

2007 Prophecy and the Near Future: Thoughts on Macroeconomic, Evangelical, and Punctuated Time. American Ethnologist 34(3):409-21.

Hannerz, Ulf

1989 Notes on the Global Ecumene. Public Culture 1(2):66-75

Hansen, Thomas Blom \& Finn Stepputat (eds)

2001 States of Imagination: Ethnographic Explorations of the Postcolonial State.

Durham, NC: Duke University Press.

Hastrup, Kirsten

2004 Kultur: Det fleksible fællesskab. Aarhus: Aarhus Universitetsforlag. 
Hobsbawm, Eric \& Terence Ranger (eds)

1983 The Invention of Tradition. Cambridge: Cambridge University Press.

Illeris, Knud (red.)

2014 Læring i konkurrencestaten. København: Samfundslitteratur.

Jenkins, Richard

2011 Being Danish. Paradoxes of Identity in Everyday Life. København: Museum Tusculanum Press.

Johansen, Mette-Louise

2013 In The Borderland: Palestinian Parents Navigating Danish Welfare State Interventions. Upubliceret ph.d.-afhandling. Aarhus: Institut for Kultur og Samfund, Aarhus Universitet.

Järvinen, Margaretha \& Nanna Mik-Meyer (red.)

2003 At skabe en klient. Institutionelle identiteter i socialt arbejde. København: Hans Reitzels Forlag.

Jöhncke, Steffen

2007 Velfærdsstaten som integrationsprojekt. I: K.F. Olwig \& K. Pærregaard (red.): Integration. Antropologiske perspektiver. Pp. 37-62. København: Museum Tusculanums Forlag.

Korsgaard, Ove

2001 Poetisk demokrati: om personlig dannelse og samfundsdannelse. København: Gads Forlag.

2004 Kampen om folket: et dannelsesperspektiv på dansk historie gennem 500 år. København: Gyldendal.

Krøijer, Stine

2013 Security Is a Collective Body: Intersecting Temporalities of Security around the Climate Summit in Copenhagen. In: M. Holbraad \& M.A. Pedersen (eds): Times of Security: Ethnographies of Fear, Protest and the Future. Pp. 37-62. New York: Routledge.

Krøijer, Stine \& Inger Sjørslev

2011 Autonomy and the Spaciousness of the Social in Denmark: The Conflict between Ungdomshuset and Faderhuset. Social Analysis 55(2):84-105.

Langer, Susanne \& Susanne Højlund

2011 An Anthropology of Welfare: Journeying towards the Good Life. Anthropology in Action 18(3):1-9.

Lauritsen, Peter

2011 Big Brother 2.0: Danmark som overvågningssamfund. København: Informations Forlag.

Lien, Marianne

2001 Likhet og verdighet. Gavebytter og integrasjon i Båtsfjord. I: M. Lien, H. Lidén \& H. Vike (red.): Likhetens paradokser. Antropologiske undersøkelser i det moderne Norge. Pp. 86-205. Oslo: Universitetsforlaget.

Lien, Marianne, Hilde Lidén \& Halvard Vike (red.)

2001 Likhetens paradokser. Antropologiske undersøkelser i det moderne Norge. Oslo: Universitetsforlaget. 
Lipsky, Michael

1980 Street-level Bureaucracy. Dilemmas of the Individual in Public Services. New York: Russel Sage Foundation.

Long, Norman

1989 Encounters at the Interface: A Perspective in Social Discontinuities in Rural Development. Wageningse Sociologische Studies 27. Wageningen: Wageningen Agricultural University.

Olwig, Karen Fog, Birgitte Romme Larsen \& Mikkel Rytter (eds)

2012 Migration, Family and the Welfare State: Integrating Migrants and Refugees in Scandinavia. London \& New York: Routledge.

Olwig, Karen Fog \& Karsten Pærregaard (eds)

2011 The Question of Integration: Immigration, Exclusion and the Danish Welfare State. Newcastle upon Tyne: Cambridge Scholars Publishing.

Papakostas, Apostolis

$2001 \quad$ Why Is There No Clientelism in Scandinavia? A Comparison of the Swedish and Greek Sequences of Development, i Clientelism, Interests, and Democratic Representation. In: S. Piattoni (ed.): The European Experience in Historical and Comparative Perspective. Cambridge: Cambridge University Press.

Pedersen, Ove Kaj

$2011 \quad$ Konkurrencestaten. København: Hans Reitzels Forlag.

2014 Markedsstaten. København: Hans Reitzels Forlag.

Politiken

2013 Corydon: Konkurrencestat er den nye velfærdsstat. 23. august.

Radcliffe-Brown, Alfred Reginald

1940 Preface. In: M. Fortes \& E.E. Evans-Pritchard (eds): African Political Systems. Oxford: Oxford University Press.

Robbins, Joel

2007 Continuity Thinking and the Problem of Christian Culture: Belief, Time, and the Anthropology of Christianity. Current Anthropology 48(1):5-37.

Rosa, Hartmut

2010 Acceleration and Alienation: Towards a Critical Theory of Late-Modernity. Aarhus: Aarhus University Press.

Rytter, Mikkel

2007 „Familien Danmark“ og „de fremmede“: Slægtskabsbilleder i dansk integrationspolitik. I: K.F. Olwig \& K. Pærregaard (red.): Integration. Antropologiske perspektiver. Pp. 63-86. København: Museum Tusculanums Forlag.

Rytter, Mikkel \& Marianne Holm Pedersen

$2014 \quad$ A Decade of Suspicion: Islam and Muslims in Denmark after 9/11. Ethnic and Racial Studies 37(13):2303-21.

Shore, Chris \& Susan Wright (eds)

1997 Anthropology of Policy. Critical Perspectives on Governance and Power, EASA. London: Routledge. 
Shore, Chris, Susan Wright \& Davide Però (eds)

2011 Policy Worlds. Anthropology and the Analysis of Contemporary Power. Oxford: Berghahn Books.

Standing, Guy

2011 The Precariat. A New Dangerous Class. London: Bloomsbury Academic.

2014 A Precariat Charter: From Denizens to Citizens. London \& New York: Bloomsbury Academic.

Strathern, Marilyn

2000 Introduction: New Accountabilities. In: M. Strathern: Audit Cultures: Anthropological Studies in Accountability, Ethics and the Academy. London: Routledge.

2011 Binary License. Common Knowledge 17(1):87-103.

Thelen, Tatjana, Larissa Vetters \& Keebet von Benda-Beckmann

2014 Introduction to Stategraphy: Toward a Relational Anthropology of the State. Social Analysis 58(3):1-19.

Togeby, Lise

1987 Politik som kultur. Politica 19:246-49.

Tynell, Jesper

2014 Mørkelygten. Embedsmænd fortæller om politisk tilskæring af tal, jura og fakta. Roskilde: Samfundslitteratur.

Vike, Halvard

2013 Utopian Time and Contemporary Time: Temporal Dimensions of Planning and Reform in the Norwegian Welfare State. In: S. Abram \& G. Weszkalnys (eds): Elusive Promises: Planning in the Contemporary World. New York \& Oxford: Berghahn Books.

2015 Likhetens natur. Norsk Antropologisk Tidsskrift 26(1):6-21.

Vaaben, Nanna

2014 Da arbejdet i samarbejdet forsvandt: Økonomiske kosmologier som optimeringslogikker i jagten på mere for mindre. Tidsskriftet Antropologi 70:11331

Weber, Max

1995 [1904] Den protestantiske etik og kapitalismens ånd. København: Nansensgade Antikvariat.

Wilk, Richard

1999 Real Belizean Food: Building Local Identity in Transnational Caribbean. American Anthropologist 101(2):244-55. 
